\title{
Biotic and abiotic risks of soil biochar treatment for food safety and human health
}

\author{
T. Kocsis ${ }^{1}$
}

e-mail: tomi.kocsis@yahoo.com

B. Ferschl ${ }^{3}$

e-mail: ferschl.barbara@kertk.szie.hu

Cs. Mohácsi-Farkas ${ }^{1}$

e-mail: farkas.csilla@etk.szie.hu
S. A. Pabar ${ }^{2}$

e-mail: pabarattila@gmail.com

Zs. Kotroczó ${ }^{2, *}$

e-mail: kotroczo.zsolt@gmail.com

${ }^{1}$ Department of Microbiology and Biotechnology, Szent István University, H-1118 Budapest, Somlói St. 14-16. Hungary

${ }^{2}$ Department of Soil Science and Water Management, Szent István University, H-1118 Budapest, Villányi St. 29-43. Hungary

${ }^{3}$ Department of Ecological and Sustainable Production Systems, Szent István University, H-1118 Budapest, Villányi St. 29-43. Hungary

\begin{abstract}
Pyrolysis technology facilitates the heating of organic waste biomass in a very low oxygen environment to temperatures over $400^{\circ} \mathrm{C}$. The high carbon content and surface area of the char produced via slow pyrolysis makes it suitable for a range of purposes that would sequester the carbon it contains. For example, there is a growing interest in its use as a soil amendment, which enhances plant growth and nutrient use efficiency.
\end{abstract}

Keywords and phrases: biochar, adsorption, PAHs, pathogens, Escherichia coli 
Biochar application to soils is being considered as a means to improve fertility while concurrently improving soil functions. Wider issues, including environmental conditions, applicational health, and safety associated with biochar production and handling, are put into context. Biochar also might contain organic and inorganic contaminants, which developed during the pyrolysis processes. The aim of this study is to measure both a biochar product's Polycyclic Aromatic Hydrocarbons (PAHs) content to get scientific basis for policy development and the potential changes in the microbial community relating to biochar soil application, with special attention to soil-borne pathogens. Based on our results, we found that biochar increased the microbial biomass values even before the incubation. In single and combined biochar-alginite treatments, more bacterial biomass was adsorbed due to the higher adhesion capability and the increased surface area. The volume of the microbial adsorption is different from species to species and even strains.

\section{Introduction}

In line with ever-changing consumer needs, the production of healthy and safe food poses increasing challenges to agriculture, food industry, and, last but not least, soil (micro-)biology professionals. The constantly degrading soils or the effects of climate change further reinforce these challenges and highlight their significance (Lajtha et al., 2018; Fekete et al., 2014; Kotroczó et al., 2020). Numerous studies report that these processes need to be mitigated. There have also been a number of studies finding the use of biochar a good solution, highlighting its positive properties (Ding et al., 2016), but only a few publications present the critical aspects of using biochar (Hardy et al., 2019).

Biochar-charcoal is an organic-related biomass material which could be produced by reductive pyrolysis (Di Blasi, 2008; Bridgwater, 2007). There is a growing interest in its use as a soil amendment, which enhances plant growth and nutrient use efficiency (Van Zwieten et al., 2010a; Shomana et al., 2020). Beneficial effects of biochar in terms of increased crop yield and improved soil quality have been reported. Its application into soil is a well-accepted process in sustainable agricultural systems, even though there are large discrepancies about its positive and negative effects. Biochar might improve the physical-chemical-biological properties of soil (Brady \& Weil, 2008) and its water retention (Shomana et al., 2020), the clay and organic matter content (Glaser et al., 1998; Lehmann et al., 2003), the pH levels (Van Zwieten et al., 2010b), and the availability of macro- and micronutrients due to its adsorption capacity (Brown et al., 2006; Chan et al., 2008). 
Data in the literature suggest that biochar products could be applied on a wide scale to influence soil-plant-microbe interactions. Biochar has a highly porous structure with a surface that can reach an area of $1,000 \mathrm{~m}^{2} / \mathrm{g}$ (Downie et al., 2009). In addition to the adsorption of various organic and inorganic substances, it provides habitats for bacteria, actinomycete, and fungi (Thies \& Rillig, 2009). The observed actions of biochar on soil microbiological activity result from at least three main effects: alteration of physico-chemical interactions, such as increased water and nutrient retention; electron donor provision; provision of habitat (Ennis et al., 2012; Chan et al., 2008). The soil microbiota need an efficient surface protection by the large absorptive capacity of biochar products and an improved water/nutrient supply. Although the combined and enhanced role of biochar and soil microbial populations in ecosystem amelioration are recognized (Fischer \& Glaser, 2012; Cocozza et al., 2017), limited research has been reported on microbial diversity/functional response to the approach. Publications on the integration of biochar into crop production technologies report yield increases, at least in the short term (Gorovtsov et al., 2019). Matsubara et al. (2002) have shown that biochar inoculated with mycorrhizal fungi is effective in reducing Fusarium root disease in an Asparagus species. In an experiment with tomato plant, Nerome et al. (2005) found that biochar from municipal organic waste reduced contamination in soil by the pathogenic bacterial wilt (Ralstonia solanacearum).

Besides the already known benefits, however, some environmental risk of biochar application was also published. Numerous studies have supported the effects of biochar on various herbicides and pesticides. Zheng et al. (2010) found that biochar efficiently adsorbed them, thereby reducing their efficiency (Yang et al., 2006). On the other hand, during the pyrolysis process, some contaminants might be created in the biochar products, which might reduce its agricultural applicability. Such contaminants are the polycyclic aromatic hydrocarbon (PAH) compounds, which might create some environmental threat (Wang et al., 2017). PAH compounds have been detected both in pyrolysis products and also during forest fires in nature (Ré-Poppi, 2002; Kim et al., 2003; Kocsis et al., 2018). Determination of the PAH content of any biochar products is of utmost importance to assess the human/environmental risk. Some authors stated (Kaal et al., 2008) that PAHs are the result of the pyrolysis process, being formed when biomass undergoes a variety of physical, chemical, and molecular changes. The PAHs' content might exceed the permissible limits of biochar products very frequently (Rajapaksha, 2016; Kocsis et al., 2018). This fact can reduce the soil applicability of biochar products when considering the environmental and food safety aspects. 
The aim of our work was to find out how biochar as a potential abiotic contaminant (PAH) affects the soil, what its biotic risk is, as it can also support the growth of microbes and opportunistic pathogens that are harmful from the point of view of food safety, and study the adhesion factors of microorganisms on species and strains level. We also aimed to provide a biochar product's $\mathrm{PAH}$ content measurement to get scientific basis for policy development and to measure the potential changes in the microbial biomass relating to biochar soil application, with special attention to soil-borne pathogens.

\section{Materials and methods}

\section{Pollution parameters}

PAH content in the applied biochar product was investigated by HPLC (CEN/TS 16181:2013), as suggested by Beni et al. (2014) and Wtóka et al. (2015). In order to provide a wide range of statistically correct results, 6 subsamples were measured for PAHs content. $30 \mathrm{ml}$ of acetonitrile was used as sample preparation for the accurately measured 1.00-gram samples. The samples were then treated for 30 minutes in an ultrasonic bath. The extracts were shaken for 24 hours. After that, extracts were purified by centrifugation and filtration through a $0.45-\mu \mathrm{m}$ pore-size PP membrane filter. The final phase of sample preparation was the concentration of extracts by using SolidPhase Extraction Technique. For this purpose, ChromaBond $\mathrm{C}_{18} 6 \mathrm{ml} / 500$ mg columns were used as follows: flow rate: $1.5 \mathrm{ml} / \mathrm{min}$, temperature: $30^{\circ} \mathrm{C}$, detector: UV $254 \mathrm{~nm}$, and injector volume: $20 \mu \mathrm{l}$.

\section{Testing of soil-borne microorganisms by biochar contaminants}

The aim was to investigate the biochar effect on soil biota. Biochar-treated slightly humus sandy soil's microbial abundance was determined by the pourplate method. 50 grams of dried and sieved $(2 \mathrm{~mm})$ soil samples were prepared in Petri dishes. The samples were subjected to the following treatments (in 4-4 replicates): A) control, no amendment, B) 5 g biochar, C) 5 g biochar +3 $\mathrm{g}$ alginite as a slow-releasing nutrient source. Water-holding capacity was set to $60 \%$, while incubation temperature was adjusted to mesophilic $\left(30 \pm 1^{\circ} \mathrm{C}\right)$ conditions for 48 hours. After incubation, the samples were decimally diluted until $1 / 10^{\text {th }}$ of the original concentration, and then $100 \mu \mathrm{l}$ of all dilution was pipetted onto Nutrient-agar media (Oxoid Ltd.) surface and spread around using a sterile glass rod. The CFU values were counted after 24 hours, $30 \pm 1^{\circ} \mathrm{C}$ incubation. 


\section{Testing of the microbial adsorption capacity}

To investigate the microbial adhesion ability on different surfaces, bacteria strains from the collection of the Department of Microbiology and Biotechnology, Szent István University (Table 1) were separately incubated in a liquid medium ( $\mathrm{pH}$ 6.6) containing glucose $(20 \mathrm{~g} / \mathrm{l})$, peptone $(10 \mathrm{~g} / \mathrm{l})$, and yeast extract $(2 \mathrm{~g} / \mathrm{l})$ until $10^{8} \mathrm{CFU} / \mathrm{cm}^{3}$ concentration. All of these species are common in the soil, and if they contaminated the raw materials, they would cause food spoilage or illness.

Table 1. Experimental strains with their incubating temperature

\begin{tabular}{|c|c|c|c|}
\hline Strain & Collection no. & $\begin{array}{l}\text { Incubation } \\
\text { temperature }\end{array}$ & Properties \\
\hline $\begin{array}{l}\text { Pseudomonas } \\
\text { aeruginosa }\end{array}$ & ATCC 27853 & $37^{\circ} \mathrm{C}$ & Opportunist pathogen \\
\hline $\begin{array}{l}\text { Pseudomonas } \\
\text { lundensis }\end{array}$ & ATCC 49968 & $30^{\circ} \mathrm{C}$ & $\begin{array}{l}\text { Causes spoilage of milk, cheese, } \\
\text { meat, and fish }\end{array}$ \\
\hline $\begin{array}{l}\text { Bacillus } \\
\text { cereus }\end{array}$ & ATCC 14579 & $30^{\circ} \mathrm{C}$ & Causes foodborne illness \\
\hline Micrococcus luteus & $\begin{array}{l}\text { ATCC } 10240 \\
\text { ATCC } 8724\end{array}$ & $30{ }^{\circ} \mathrm{C}$ & Opportunist pathogen \\
\hline $\begin{array}{l}\text { Escherichia coli } \\
\text { (four strains) }\end{array}$ & $\begin{array}{l}\text { ATCC } 8739 \\
\text { ATCC } 25992 \\
\text { ATCC } 43895\end{array}$ & $37^{\circ} \mathrm{C}$ & Opportunist pathogen \\
\hline
\end{tabular}

In the measurement, sterilized soil column was prepared in three different treatments. The soil was pre-treated by $\gamma$-irradiation with $20 \mathrm{kGy}$ doses (1600 TBq activity of 60Co source). The assay followed OECD Test No. 312: "Leaching in Soil Columns" protocol. The following treatments were set in 4-4 replicates: A) control, 50 g soil; B) $45 \mathrm{~g}$ soil +5 g biochar; C) $40 \mathrm{~g}$ soil +5 $\mathrm{g}$ biochar $+5 \mathrm{~g}$ alginite. Two pieces of filter paper were placed on the plastic plate to avoid the outflow of soil particles from the soil column. A sterilized (autoclave $121^{\circ} \mathrm{C}, 21 \mathrm{~min}$ ) $15 \mathrm{~mm}$ thick quartz sand layer was also added on the top and bottom of the soil to facilitate a uniform distribution of the eluent. After the preparation, $100 \mathrm{ml}$ sterile deionized water was added to the column to restore moisture content. After flowing down, $100 \mathrm{ml}$ separately prepared liquid bacteria culture was also added. The leachate was later collected by a $250 \mathrm{ml}$ flask under the soil column, and its volume was recorded. A total of 12 samples of leachate (each sample contained approximately $200 \mathrm{ml}$ of leachate in volume) for each soil column were collected. Finally, the microbial 
concentration of the leachate was also determined by pour-plate method.

\section{Data analysis}

For evaluation of the results, one-way ANOVA test was applied. Normality assumption was proven by Kolmogorov-Smirnov test $(\mathrm{p}>0.05, \mathrm{p}=0.200)$ or Shapiro-Wilk test $(\mathrm{p}>0.05)$, and the homogeneity of variances was checked by Levene's test $(\mathrm{p}>0.05)$. Where data had homogeneity of variance, Tukey's honestly significant difference (HSD) post-hoc test was used, and where the data were 131 heteroscedastic, Games-Howell's post-hoc analysis was applied. The differences are presented with the letters a, b, c, and d over the corresponding column of the graph. As above, the significantly highest group is denoted with the letter a, the next highest with $\mathrm{b}$, c, and this pattern continues up to letter $\mathrm{d}$, if needed.

\section{Results and discussion}

Risk assessment of biochar samples

Even though soil properties can be improved by biochar application, concern should be given to proper biochar quality. As it was reviewed by Kocsis et al. (2016), the biochar might contain chemicals of persistent organic pollutants, which may reduce its general agricultural applicability. The levels of various $\mathrm{PAH}$ compounds were assessed from several biochar samples of agricultural origin. Results are shown in Table 2.

As we found beforehand (Kocsis et al., 2018), the PAH concentration of the biochar sample exceeded the permissible limit value of the $1 \mathrm{mg} \cdot \mathrm{kg}^{-1}$ product (Table 2). There is an International Biochar Initiative, which recommends classification tools regarding the nutrient and PAH content of these pyrolysed products, but it is not a widespread norm. In Hungary, there is a standard and a decision of the Hungarian Agricultural and Land Management Ministry (36/2006.V. 18. FvM) on yield-enhancing materials. Furthermore, the Hungarian soil conservation and protection law (129/2007) also stated that caution is needed with any products with a potential of soil application. The $\mathrm{PAH}$ concentration in biochar-treated soils cannot exceed the level of $1 \mathrm{mg} / \mathrm{kg}$ on a dry soil basis. Neither of the adjusted biochar-soil treatments exceeded the statutory requirement.

Compared to the control after 48 hours at $30^{\circ} \mathrm{C}$ temperature, both the biochar and biochar + alginite treatments showed a one-order increase in log 
CFU values after the start of the incubation (Figure 1) - these increased values were significant based on the ANOVA test result. The sterile biochar did not contain microorganisms (due to incineration and lack of water), wherefore the explanation might be that biochar provided additional nutrients and space (niche) for microbial growth. Numerous studies report that due to its porous structure, biochar is not only able to bind certain substances, but the large surface area also promotes the adhesion of microorganisms, providing habitat for them (Lehmann et al., 2011; Abujabhah et al., 2016).

Table 2. Characteristics and levels of various Polycyclic Aromatic Hydrocarbon (PAH) compounds of the biochar product

\begin{tabular}{lc}
\hline Characteristics & Biochar \\
\hline Raw material & Separated cow manure/wood chips $(80: 20 \%)$ \\
Obtaining temperature & $\left({ }^{\circ} \mathrm{C}\right) 650-750$ \\
pH (water) & 9.66 \\
Total dissolved solids $(\mathrm{mg} / \mathrm{kg})$ & 2125 \\
PAH compounds $(\mu \mathbf{g} / \mathbf{g})$ & \\
Anthracene & 0.1209 \\
Benzo[a]anthracene & 0.3276 \\
Benzo[b]fluoranthene & n.d. \\
Benzo[a]pyrene & n.d. \\
Chrysene & 7.3454 \\
Fluoranthene & 2.4044 \\
Fluorene & 0.4437 \\
Phenanthrene & n.d. \\
Pyrene & n.d. \\
SUM & $\mathbf{1 0 . 6 4 1 9}$ \\
\hline
\end{tabular}

The content of some polycyclic aromatic hydrocarbon (PAH) compounds was measured by the HPLC method.

The short time between mixing the biochar in the soil and the measurement was sufficient for this increase. The same results can be observed for biochar + additions, with slightly higher values compared to the single biochar treatment and a higher rate of increase after incubation, which can be explained by the slower exploration of alginite. As biochar, alginite has a number of beneficial properties. It improves soil structure, has a significant content of minerals and organic matter, and contributes to improving soil biological activity and thus fertility (Borowik \& Wyszkowska, 2018; Strachel et al., 2018). In this case, the alginite could not be revealed due to the short measurement period, which could be the reason why no statistically substantiated differences between the biochar and the biochar + alginite treatments were found. 


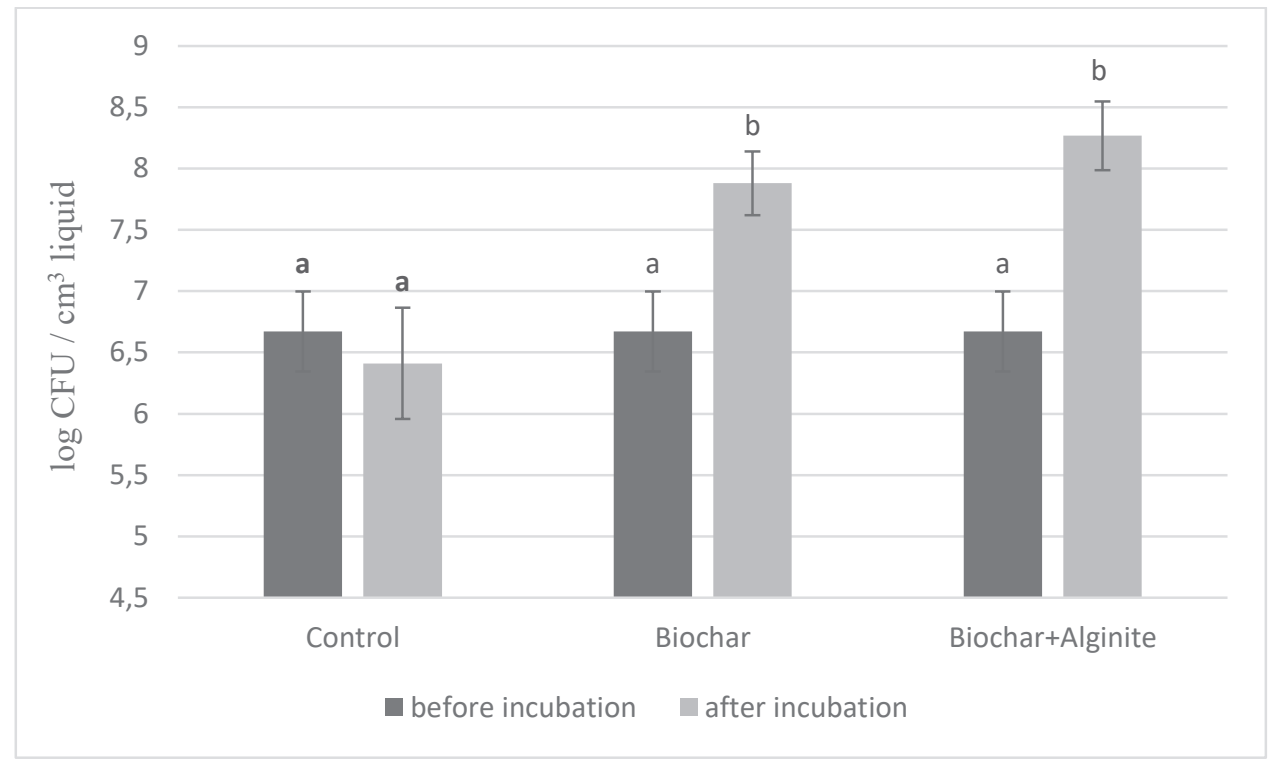

Figure 1. Development of CFU cultivable germ count values under the influence of biochar and biochar + alginite compared to the untreated control

The $\log$ CFU values of pure cultures filtered through soil columns were significantly lower in the biochar and biochar + alginite treatments compared to the control. This means that the biochar and the combined biochar-alginite treatments adsorbed more bacteria, which is due to the higher adhesion capability and the larger surface area. Elmer et al. (2010) reported a similar result in their work with Asparagus. In their experiment, they observed a decrease in the number of Fusarium fungi in biochar-treated soils. Likewise, Ogawa (2010) describes the use of biochar and biochar-amended composts in reducing bacterial and fungal soil-borne diseases.

There was no significant difference between biochar and biochar + alginite treatments, except for one Escherichia coli strain ATCC 8739 (Figure 3), where the biochar-alginite combination produced a synergistic effect compared to the single biochar treatment.

The microbial adsorption capacity rate of the cultures also varied with species and strain levels (figures 2 and 3). The measured Pseudomonas aeruginosa strain leached in greater values than Pseudomonas lundensis, Bacillus cereus, and Micrococcus luteus (Figure 2). 


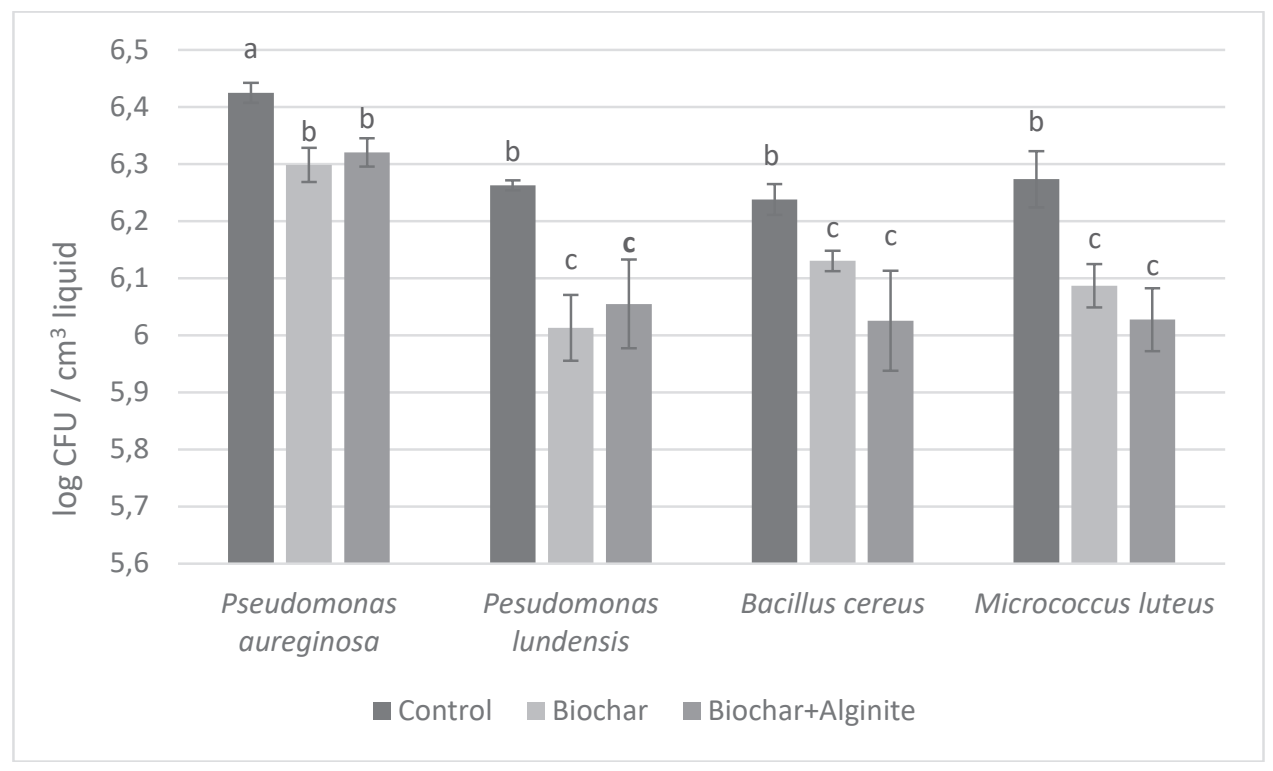

Figure 2. The number of the different bacteria under the influence of biochar + alginite, compared after leaching through a soil column

In the case of $E$. coli, the leaching properties show also diverse results, suggesting differences in the microbial adhesion factors (Figure 3). The ATCC 43895 (O157:H7) strain produced the largest binding compared to the control, while ATCC 8739 uniquely shows a significant difference between the combined biochar-alginite and the single biochar treatments. The CFU concentration of the starting liquid was "log 8 ". The soil columns reduced the number of bacteria in the liquid by orders of magnitudes of 1.4-2.1. Based on the reduction, more bacteria remained in the leached column; thus, the biochar-treated soil may potentially pose a greater food safety risk of pathogenic microbes.

There is a huge variability in biochar structures depending on the parent material and the conditions present at their formation. This determines many properties of biochar, including how many, if any, microorganisms are able to adhere to its surface (Czimczik \& Masiello, 2007). Several studies reported that different groups of microbes are able to bind to biochar to varying degrees.

The reasons for changes in microbial abundance may differ for the different groups of microorganisms (Warnock et al., 2007; Lehmann et al., 2011). 


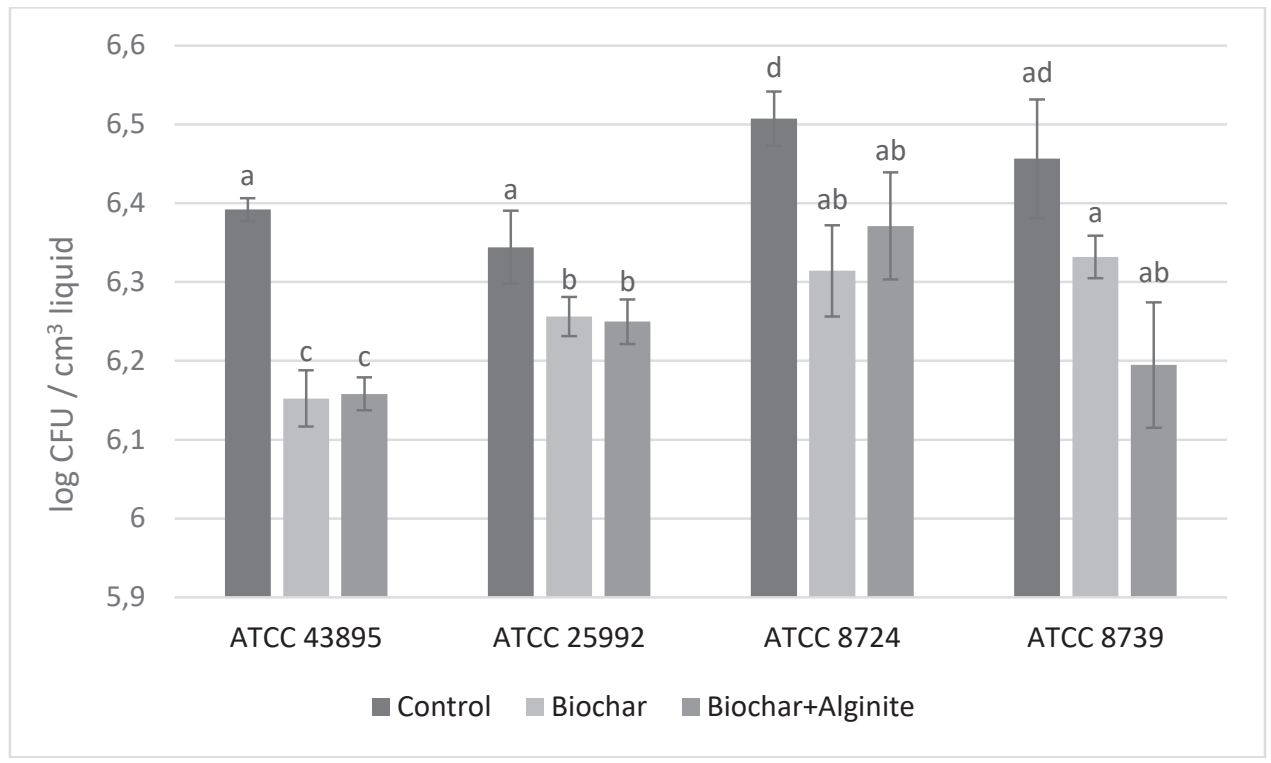

Figure 3. The number of different Escherichia coli strains under the influence of biochar + alginite, compared after leaching through a soil column

Differences in the adsorption of microbe species or strains onto biochar are explained by phenomena such as sorption of signalling compounds, detoxification of allelochemicals, soil physico-chemical properties, or indirect effects through alterations of other soil microbial processes (Warnock et al., 2007; Elmer \& Pignatello, 2011; Lehmann et al., 2011).

\section{Conclusions}

Based on the results of this study, the main risks of the biochar products of various industrial technologies cover two main directions. One of them is the risk of PAH content, which might diminish the proper nutrient availability of crops in arable soils. The other direction is the microbiological contamination of the changed soil niche. Increased countable microorganism number can be adsorbed by biochar application, which helps soil life by providing additional nutrients and ecological space in the treated soil, which also supports the survival of pathogens. In this case, the added alginite did not yield a significantly different result compared to biochar treatment. The measurement of micro- 
bial adsorption capacity revealed that biochar and biochar-alginite treatments adsorbed microbes in higher amount, and so they can be found in higher numbers, which is also a food safety issue. The magnitude of these changes is different from species to species and even strains. Thus, it is difficult to determine why there might be such a difference between individual microbial strains in their binding to biochar. However, it supports our hypothesis that potentially pathogenic microbial strains need to be tested separately based on their adsorption affinity to biochar. Based on our results, we can state that their different binding determines the amount of microbes in biochar-enriched soils, and thus they can pose a food safety risk even if they are too enriched.

\section{Conflict of interest}

The authors declare that there are no conflicts of interest.

\section{Acknowledgement}

The project is supported by the European Union and co-financed by the European Social Fund (Grant Agreement No. EFOP-3.6.3-VEKOP-16-2017-00005, EFOP-3.6.1-16-2016-00016).

\section{References}

[1] Abujabhah, I. S., Bound, S. A., Doyle, R., Bowman, J. P., Effects of biochar and compost amendments on soil physico-chemical properties and the total community within a temperate agricultural soil. Applied Soil Ecology, 98. (2016) 243-253.

[2] Béni, A., Soki, E., Lajtha, K., Fekete, I., An optimized HPLC method for soil fungal biomass determination and its application to a detritus manipulation study. Journal of Microbiological Methods, 103. (2014) 124-130.

[3] Borowik, A., Wyszkowska, J., Remediation of soil contaminated with diesel oil. Journal of Elementology, 23. (2018) 767-788.

[4] Brady, N. C., Weil, R. R., The nature and properties of soils. $14^{\text {th }}$ ed. Pearson Prentice Hall, Upper Saddle River, NJ (2008). 
[5] Bridgwater, A. V., IEA Bioenergy Update 27: Biomass Pyrolysis. Biomass and Bioenergy, 31. (2007) 1-5.

[6] Brown, R. A., Kercher, A. K., Nguyen, T. H., Nagle, D. C., Ball, W. P., Production and characterization of synthetic wood chars for use as surrogates for natural sorbents. Organic Geochemistry, 37. (2007) $321-333$.

[7] Chan, K. Y., Van Zwieten, L., Meszaros, I., Downie, A., Joseph, S., Agronomic values of greenwaste biochar as a soil amendment. Soil Research, 45. (2008) 629-634.

[8] Cocozza, C., Baronti, S., Amendola, C., Vaccari, F. P., Lustrato, G., Lonardo, S. D., Fantasma, F., Tognetti, R., Scippa, G. S., The effects of biochar and its combination with compost on lettuce (Lactuca sativa L.) growth, soil properties, and soil microbial activity and abundance. International Journal of Agronomy (2017).

[9] Czimczik, C. I., Masiello, C. A., Controls on black carbon storage in soils. Global Biogeochemical Cycles, 21. (2007).

[10] Di Blasi, C., Modeling chemical and physical processes of wood and biomass pyrolysis. Progress in Energy and Combustion Science, 34. (2008) 47-90.

[11] Ding, Y., Liu, Y., Liu, S., Li, Z., Tan, X., Huang, X., Zheng, B., Biochar to improve soil fertility. A review. Agronomy for Sustainable Development, 36. (2016).

[12] Downie, A., Munroe, P., Crosky, A., Characteristics of biochar - Physical and structural properties. In: Lehmann J., Joseph S. (eds.), Biochar for environmental management: Science and technology. Earthscan, London (2009) 13-29.

[13] Elmer, W., White, J. C., Pignatello, J. J., Impact of biochar addition to soil on the bioavailability of chemicals important in agriculture. Report. New Haven: University of Connecticut (2010).

[14] Elmer, W. H., Pignatello, J. J., Effect of biochar amendments on mycorrhizal associations and Fusarium crown and root rot of asparagus in replant soils. Plant Disease, 95. (2011) 960-966. 
[15] Ennis, C. J., Evans, A. G., Islam, M., Ralebitso-Senior, T. K., Senior, E., Biochar: Carbon sequestration, land remediation, and impacts on soil microbiology. Critical Reviews in Environmental Science and Technology, 42. (2012) 2311-2364.

[16] Fekete, I., Varga, Cs., Nagy, P. T, Tóth, J. A., Kotroczó, Zs., Effect of detritus input on some soil nutrients concentrations in a Central European deciduous forest. In: Rıdvan, K., Coşkun, G. (eds.), Book of Proceedings: $9^{\text {th }}$ International Soil Science Congress on "The Soul of Soil and Civilization", 14-16 October 2014, Side, Antalya/Turkey (2014) 461-467.

[17] Fischer, D., Glaser, B., Synergisms between compost and biochar for sustainable soil amelioration. In: Kumar, S., Bharti, A. (eds.), Management of organic waste. IntechOpen (2012) 167-198.

[18] Glaser, B., Haumaier, L., Guggenberger, G., Zech, W., Black carbon in soils: The use of benzenecarboxylic acids as specific markers. Organic Geochemistry, 29. (1998) 811-819.

[19] Gorovtsov, A. V., Minkina, T. M., Mandzhieva, S. S., Perelomov, L. V., Soja, G., Zamulina, I. V., Yao, J., The mechanisms of biochar interactions with microorganisms in soil. Environmental Geochemistry and Health, 1-24. (2019).

[20] Hardy, B., Sleutel, S., Dufey, J. E., Cornelis, J. T., The long-term effect of biochar on soil microbial abundance, activity and community structure is overwritten by land management. Frontiers in Environmental Science, 7. 110. (2019).

[21] Kaal, J., Brodowski, S., Baldock, J. A., Nierop, K. G., Cortizas, A. M., Characterisation of aged black carbon using pyrolysis-GC/MS, thermally assisted hydrolysis and methylation (THM), direct and crosspolarisation ${ }^{13} \mathrm{C}$ nuclear magnetic resonance (DP/CP NMR) and the benzenepolycarboxylic acid (BPCA) method. Organic Geochemistry, 39. (2008) 1415-1426.

[22] Kim, E. J., Oh, J. E., Chang, Y. S., Effects of forest fire on the level and distribution of PCDD/Fs and PAHs in soil. Science of the Total Environment, 311. (2003) 177-189. 
[23] Kocsis, T., Biró, B., Mátrai, G., Ulmer, Á., Kotroczó, Zs., Effect of plant-coal biochar on soil organic matter and soil nutrient content. Kertgazdaság [Horticulture] 48. (2016) 89-96. (in Hungarian with English abstract).

[24] Kocsis, T., Biró, B., Ulmer, Á., Szántó, M., Kotroczó, Zs., Time-lapse effect of ancient plant coal biochar on some soil agrochemical parameters and soil characteristics. Environmental Science and Pollution Research, 25. (2018) 990-999.

[25] Lajtha, K., Bowden, R. D., Crow, S., Fekete, I., Kotroczó, Zs., Plante, A., Simpson, M., Nadelhoffer, K., The Detrital Input and Removal Treatment (DIRT) network. Reference Module in Earth Systems and Environmental Sciences (2017).

[26] Kotroczó, Zs., Juhos, K., Biró, B., Kocsis, T., Pabar, S. A., Varga, C., Fekete, I., Effect of detritus manipulation on different organic matter decompositions in temperate deciduous forest soils. Forests, 11. (2020) 675 .

[27] Lehmann, J., Kern, D. C., German, L. A., McCann, J., Martins, G. C., Moreira, A., Soil fertility and production potential. In: Lehmann, J., Kern, D. C., Glaser, B., Woods, W. I. (eds.), Amazonian dark earths: Origin, properties, management. Kluwer Academic Publishers, Dordrecht (2003) 105-124.

[28] Lehmann, J., Rillig, M. C., Thies, J., Masiello, C. A., Hockaday, W. C., Crowley, D., Biochar effects on soil biota - A review. Soil Biology and Biochemistry, 43. (2011) 1812-1836.

[29] Matsubara, Y. I., Hasegawa, N., Fukui, H., Incidence of Fusarium root rot in asparagus seedlings infected with arbuscular mycorrhizal fungus as affected by several soil amendments. Journal of the Japanese Society of Horticultural Science, 71. (2002) 370-374.

[30] Nerome, M. K., Toyota, T. M. D., Islam, T., Nishijima, T., Matsuoka, K. S., Yamaguchi, Y., Suppression of bacterial wilt of tomato by incorporation of municipal biowaste charcoal into soil. Soil Microorganisms, 59. (2005) 9-14.

[31] Ogawa, M., Okimori, Y., Pioneering works in biochar research, Japan. Soil Research, 48. (2010) 489-500. 
[32] Organisation for Economic Co-Operation and Development. Test No. 312: Leaching in soil columns. OECD Publishing (2004).

[33] Rajapaksha, A. U., Chen, S. S., Tsang, D. C., Zhang, M., Vithanage, M., Mandal, S., Ok, Y. S., Engineered/designer biochar for contaminant removal/immobilization from soil and water: Potential and implication of biochar modification. Chemosphere, 148. (2016) 276-291.

[34] Ré-Poppi, N., Santiago-Silva, M., Identification of polycyclic aromatic hydrocarbons and methoxylated phenols in wood smoke emitted during production of charcoal. Chromatographia, 55. (2002) 475-481.

[35] Shomana, T., Botha, D. E., Agachi, P. S. The water retention properties of biochar derived from broiler poultry litter as applied to the Botswana soil. DRC Sustainable Future, 1. (2020) 67-72.

[36] Strachel, R., Wyszkowska, J., Baćmaga, M., An evaluation of the effectiveness of sorbents in the remediation of soil contaminated with zinc. Water, Air, \& Soil Pollution, 229. (2018) 235.

[37] Thies, J. E., Rillig, M. C., Characteristics of biochar: Biological properties. In: Lehmann J., Joseph S. (eds.), Biochar for environmental management. Earthscan Publications Ltd (2009) 85-105.

[38] Van Zwieten. L., Kimber. S., Downie. A., Morris. S., Petty. S., Rust, J., Chan, K. Y., A glasshouse study on the interaction of low mineral ash biochar with nitrogen in a sandy soil. Australian Journal of Soil Research, 48. (2010a) 569-576.

[39] Van Zwieten, L., Kimber, S., Morris, S., Chan, K. Y., Downie, A., Rust, J., Joseph, S., Cowie, A., Effects of biochar from slow pyrolysis of papermill waste on agronomic performance and soil fertility. Plant and Soil, 327. (2010b) 235-246.

[40] Wang, X., Zhao, F., Zhang, G., Zhang, Y., Yang, L., Vermicompost improves tomato yield and quality and the biochemical properties of soils with different tomato planting history in a greenhouse study. Frontiers in Plant Science, 8. (2017) 1978.

[41] Warnock, D. D., Lehmann, J., Kuyper, T. W., Rillig, M. C., Mycorrhizal responses to biochar in soil - Concepts and mechanisms. Plant and Soil, 300. (2007) 9-20. 
[42] Włóka, D., Kacprzak, M., Grobelak, A., Grosser, A., Napora, A., The impact of PAHs contamination on the physicochemical properties and microbiological activity of industrial soils. Polycyclic Aromatic Compounds, 35. (2015) 372-386.

[43] Yang, Y. N., Sheng, G. Y., Huang, M. S., Bioavailability of diuron in soil containing wheat-straw-derived char. Science of the Total Environment, 354. (2006) 170-178.

[44] Zhang, A., Cui, L., Pa, G., Li, L., Hussain, Q., Zhang, X., Zheng, J., Crowley, D., Effect of biochar amendment on yield and methane and nitrous oxide emissions from a rice paddy from Tai Lake plain, China. Agriculture, Ecosystems and Environment, 139. (2010) 469e-475. 